\title{
Production of specific pathogen-free larvae from genetically characterized populations of Anadara tuberculosa (Bivalvia), for stock enhancement and aquaculture in the Peru Northeast Biosphere Reserve
}

\author{
Benoit Diringer $^{1,7}$, Violeta Moreno ${ }^{2}$, Krizia Pretell ${ }^{3}$, Ricardo Avellan ${ }^{4}$, Mélanie Sahuquet ${ }^{1,7}$ \\ Ritchie Vasquez ${ }^{5}$, Gabriele Gentile ${ }^{6}$ \& Eric Mialhe ${ }^{1,4}$ \\ ${ }^{1}$ INCA ${ }^{\prime}$ BIOTEC SAC, Tumbes, Perú \\ ${ }^{2}$ MARINAZUL S.A., La Victoria, Lima, Perú \\ ${ }^{3}$ MDA Subsidiary Lima, Perú \\ ${ }^{4}$ Concepto Azul, Guayaquil, Ecuador \\ ${ }^{5}$ Inversiones SILMA SAC, Tumbes, Perú \\ ${ }^{6}$ Department of Biology, University of Rome Tor Vergata, Rome, Italy \\ ${ }^{7}$ EPHE, CEDI, UMR DGIMI 1333, Université Montpellier 2, Montpellier, France \\ Corresponding author: Benoit Diringer (diringerb@yahoo.fr)
}

\begin{abstract}
The pustulose ark, Anadara tuberculosa, is considered as an emblematic species of the east Pacific mangrove ecosystem. The decline of its populations is of increasing preoccupation, in particular in Peru. The use of hatchery-produced larvae for stock enhancement or aquaculture is attractive but raises strong criticisms from an ecological point of view, as it could conduce to loss of genetic diversity in wild populations and favor the disease spreading from hatcheries to the environment. In this works, spat production through traditional aquaculture/biotechnology technologies was associated with pathogen molecular diagnostics and with genetic diversity estimation to produce specific pathogen-free (SPF) larvae from genetically characterized populations. All PCR and nested-PCR diagnostics of common bivalve pathogens, such as Bonamia, Martelia, Perkinsus and OsHV1, led to negative results for healthy or moribund adults and spat samples. Microbiological and molecular analyses realized during mortalities led to identifying a pathogenic Pseudomonas strain present on culture tank walls, in moribund spats and adults' blood. Population genetic variation was assessed by mitochondrial COI gene sequences which showed $36.7 \%$ haplotype diversity. This study with hatchery production, pathology and genetic components for an overexploited native bivalve represents an original model for successful mollusk stock enhancement or/and innovative aquaculture programs.
\end{abstract}

Keywords: Anadara tuberculosa; specific pathogen-free larvae; genetic diversity; stock enhancement; aquaculture

\section{INTRODUCTION}

The pustulose ark Anadara tuberculosa (Mollusca, Bivalvia) is distributed from the Gulf of California in Mexico to the Tumbes region in northern Peru (Baqueiro et al., 1982). Natural banks of this species develop in muddy sediments, in particular around the roots of the red mangrove, Rhizophora mangle (Camacho, 1999). This ark is a symbolic species of the eastearn Pacific mangrove ecosystem that has been ancestrally collected by coastal populations as a staple food, and that is still consumed for traditional meals in several tropical Latin American countries. Extraction is an essential activity for numerous families whose economy relies on A. tuberculosa trade. Most of the natural stocks of $A$. tuberculosa are vulnerable, and some populations are close to collapse in several countries (Lucero et al., 2012; Mora et al., 2011). In Peru, the A. tuberculosa population of Tumbes region has been reduced by 6.4 fold between 1988 and 2008 in unprotected mangrove areas as well as in the protected area of the National Sanctuary Mangrove of Tumbes

Corresponding editor: Sandra Bravo 
(NSMT) (Vivar, 1996; Ordinola et al., 2010). The diminution of $A$. tuberculosa population is attributed to overexploitation and habitat degradation, but could also result from covert mortalities due to infectious diseases (Gaffney, 2006).

Recuperation strategies generally rely on quota implementation with, on the one hand, permanent collection restrictions based on animal minimum size limits and, on the other hand, occasional collection prohibitions during reproductive seasons to recover depleted aquatic animal stocks. Such regulations are more or less respected and are complicated by their economic consequences for fishers. Another strategy component for retrieving aquatic animal stocks is based on habitat restoration (McCay et al., 2003).

Strategy for restocking and enhancing stocks of natural aquatic populations has also been focused on the mass release of hatchery-produced animals (Bell et al., 2005; Arnold et al., 2005; Arnold, 2008). Such a strategy is attractive for aquatic species, in particular, mollusks, considering their extremely high fecundity and the subsequent possibility to produce in hatchery millions of spat from a numerically limited wild broodstock. However, serious concerns are related to such a strategy, in particular for preventing infectious diseases that could be vertically transmitted and then quickly sprayed from hatchery to the field and for maintaining population genetic diversity that could be rapidly reduced from numerically limited broodstock. The proper management of these pathology and genetics concerns is a priority for successful mollusk stock enhancement and/or new species aquaculture programs.

For several decades, mollusk cultures all around the world have suffered numerous outbreaks caused by infectious diseases with severe productive and socioeconomic losses. Such problems result from the lack of preventive consideration for contagious diseases related to several types of pathogens, in particular, some highly pathogenic protozoans, bacteria, rickettsia and viruses (Berthe, 2005; Powell \& Hofman, 2015; Guo \& Ford, 2016). These mollusk's infectious microorganisms may be vertically or horizontally transmissible from asymptomatic infected broodstocks to their larvae (Arzul et al., 2010; López-Sanmartín et al., 2016).

For stock enhancement or aquaculture programs, such a pathogen transmission risk must be prevented through pathogen free certification of broodstock in the hatchery. Considering the lack of information on infectious diseases for non-cultivated mollusk species like A. tuberculosa, a first approach would rely on specific pathogen-free certification (SPF) of broodstock considering in priority the various pathogens identified in other bivalve species, such those listed by the OIE (International Office of Epizootics).

Shellfish hatchery-reared larvae may lead to reduced genetic diversity, resulting from a limited number of brooders and/or to higher fitness of some genotypes in artificial culture conditions. Genetic diversity is a crucial component for population adaptive response to environmental conditions and long-term viability of aquaculture or stock enhancement programs. Consequently, the production and release of hatchery-reared larvae must be performed considering the management of genetic diversity at intra- and interpopulation levels. Such considerations have been reviewed with three major genetic concerns relevant to shellfish restoration projects (Gaffney, 2006; Lallias et al., 2010). The broodstock must be identified and selected by genetic characterizations of all the populations in the geographical area of the species. The genetic variability intra- and interpopulation must be conserved as high as possible, and as representative as possible of the different populations to avoid inbreeding or genetic drifts. The actual impact of hatchery-propagated spat introduction on the wild populations must be assessed.

Given all these concerns, suitable and reliable genetic markers are necessary for the proper management of the native genetic pool. Mitochondrial DNA (mtDNA) cytochrome $c$ oxidase subunit I gene (COI) has been successfully used for characterizing interspecific and intraspecific variability in different mollusks, in particular for arks shells in Asia (Cho et al., 2007; Chee et al., 2011a; Feng et al., 2011; Tanaka \& Aranishi, 2013, 2014, 2016), and was thus applied to characterize Anadara tuberculosa population genetic structure within the NSMT.

The production of A. tuberculosa spat in hatchery has been achieved firstly by Robles-Mungaray (1999) with conditioned brooders. Successful seed production has also been reported later by the Centro de Desarrollo de la Pesca y la Acuicultura (CENDEPESCA) (Vásquez et al., 2009). However, these productions have not yet considered the pathology and genetic concerns previously explained.

The present project has been aiming at the development of methodologies for sustainable spat production as a crucial step towards the implementation of an effective conservation strategy for A. tuberculosa, fostering alternatives to extraction through social aquaculture and stock enhancement.

The project herein described rested on three core components, integrating A. tuberculosa spat production with pathogen-free certification and population genetic characterization. 


\section{MATERIALS AND METHODS}

\section{Wild animals}

Animals were collected from September 2010 to March 2011 by certified extractors within the area of the National Sanctuary Mangrove of Tumbes (NSMT), located from Boca de Capones and International Channel $\left(3^{\circ} 18^{\prime} S\right)$ to Playa Hermosa $\left(3^{\circ} 35^{\prime} \mathrm{S}\right)$, and $80^{\circ} 13^{\prime} 08^{\prime \prime} \mathrm{W}$ to $80^{\circ} 31^{\prime} 53^{\prime \prime} \mathrm{W}$ (Zarumilla, Peru). Five to $10 \%$ of the animals from each batch were sacrificed to evaluate the state of gonadal maturation and to select batches with the highest proportion of ripe animals. The animals were transported to the laboratory, washed and placed into fiberglass tanks. They were then placed in suspended baskets with clean water for $24 \mathrm{~h}$ without food to empty their stomach contents from waste.

For genetic analysis, animals of any size were sampled at 7 extraction sites: Z1) La Abeja $3^{\circ} 25^{\prime} \mathrm{S}$, $\left.80^{\circ} 16^{\prime} \mathrm{W}, \mathrm{Z} 2\right)$ Chorro de la Almeja $3^{\circ} 24^{\prime} \mathrm{S}, 80^{\circ} 18^{\prime} \mathrm{W}$, Z3) El Habilitado $3^{\circ} 25^{\prime} \mathrm{S}, 80^{\circ} 17^{\prime} \mathrm{W}$, Z4) La Chalaquera $\left.3^{\circ} 25^{\prime} \mathrm{S}, 80^{\circ} 16^{\prime} \mathrm{W}, \mathrm{Z5}\right)$ Corral de los Coches $3^{\circ} 25^{\prime} \mathrm{S}$, $80^{\circ} 15^{\prime} \mathrm{W}, \mathrm{Z6}$ ) Nacupillal $3^{\circ} 25^{\prime} \mathrm{S}, 80^{\circ} 15^{\prime} \mathrm{W}, \mathrm{Z7}$ ) Las Agujillas $3^{\circ} 25^{\prime} \mathrm{S}, 80^{\circ} 13^{\prime} \mathrm{W}$, and tissues were collected the same day for analysis.

\section{Spat production}

Egg spawning and larval rearing were realized at Marinazul's hatchery $\left(3^{\circ} 54^{\prime} \mathrm{S}, 80^{\circ} 52^{\prime} \mathrm{W}\right)$. Maturation of broodstock and induction of gamete emission were performed considering information published by Helm et al. (2004) and Vásquez et al. (2009). Thermal shock induced gametes emission with a gradual temperature increase $\left(+5^{\circ} \mathrm{C}\right)$. When animals started to spawn or ejaculate, they were transferred individually into $1 \mathrm{~L}$ recipients where they finished gametes emission. Gametes were easily identified by their color, with white sperms and orange ova being mixed for fertilization. Fertilized eggs were kept in aerated tanks to continue larval rearing.

Swimming D larvae were manually harvested and placed in cylindroconical tanks at five larvae $\mathrm{mL}^{-1}$. The tanks were drained daily or at intervals of one day. The temperature was kept between $24-29^{\circ} \mathrm{C}$ and salinity was kept at 35 . A feeding with microalgae was supplied immediately after water changes. Several complementary feedings had permitted to maintain constant food availability. Diets during the first days were based on the flagellated microalgae Isochrysis galvana and Pavlova lutherii. From the third day, Chaetoceros calcitrans and Chaetoceros gracilis were included in the diet to reach a rate of $60 \%$ gradually.

When larvae exhibit settlement behavior, they were transferred in the black cylindrical settlement at a density of $100 \mathrm{~cm}^{-2}$ without substrate until the metamorphosis. The settled larvae were fed with an increasing quantity of microalgae that must be regularly monitored to verify feed availability until they can be harvested (about $1 \mathrm{~mm}$ shell length) by scraping the tank bottom delicately. The harvested spats were placed in baskets suspended in black cylindrical tanks $(500 \mathrm{~L})$ until they reach a $4-5 \mathrm{~mm}$ size that is suitable for transfer for aquaculture or stock enhancement experiments.

\section{Samples collection}

The samples for microbiological or DNA analysis were obtained from different methods and tissues according to the purpose. After collection from the NSMT, healthy Anadara tuberculosa brooders were brushed to eliminate attached material and placed in $1 \mathrm{~L}$ plastic box filled with filtered seawater. After 4 to $12 \mathrm{~h}$, feces were collected using a $1 \mathrm{~mL}$ disposable pipette. Thus, brooder's blood was aseptically collected by inserting a 25 gauge needle attached to a $1 \mathrm{~mL}$ syringe directly into the posterior adductor muscle. Blood was mix v/v with $10 \%$ sodium citrate as an anticoagulant. For moribund broodstock, the animals were carefully opened and samples of gills, mantle or digestive gland were excised. All tissues were deposited in $2 \mathrm{~mL}$ microcentrifuge tubes and directly processed. Larvae were obtained by filtering with a mesh size according to the larval stage and washed three times with sterile saline solution $(0.2 \%)$. Biofilm sample was collected from the tank surface by removing the biofilm with sterile saline water, detached with a sterile cotton swab and suspended in sterile saline solution.

\section{DNA extraction}

For molecular analysis, total genomic DNA was individually extracted from approximately $100 \mathrm{mg}$ of tissue that could be spats, gill, and mantle, digestive gland, blood or feces according to the purpose (Table 1) using a standard CTAB protocol (Folmer et al., 1994).

\section{Microbiological analyses}

Bacterial isolation was performed from moribund larvae or brooders 'blood'. Bacteria were isolated and purified using TSA and Cetrimide mediums enriched with $2 \% \mathrm{NaCl}$ and TCBS. Plates were incubated for 18 to $24 \mathrm{~h}$ at $28^{\circ} \mathrm{C}$, all phenotypically distinguishable colonies were picked, and additionally, about 2-4 per plates were randomly selected to isolate as many different strains as possible. The streaking method and purity realized Gram coloration assessed the purification process. The purification process was repeated until obtaining pure colonies and then cultivated in LB 


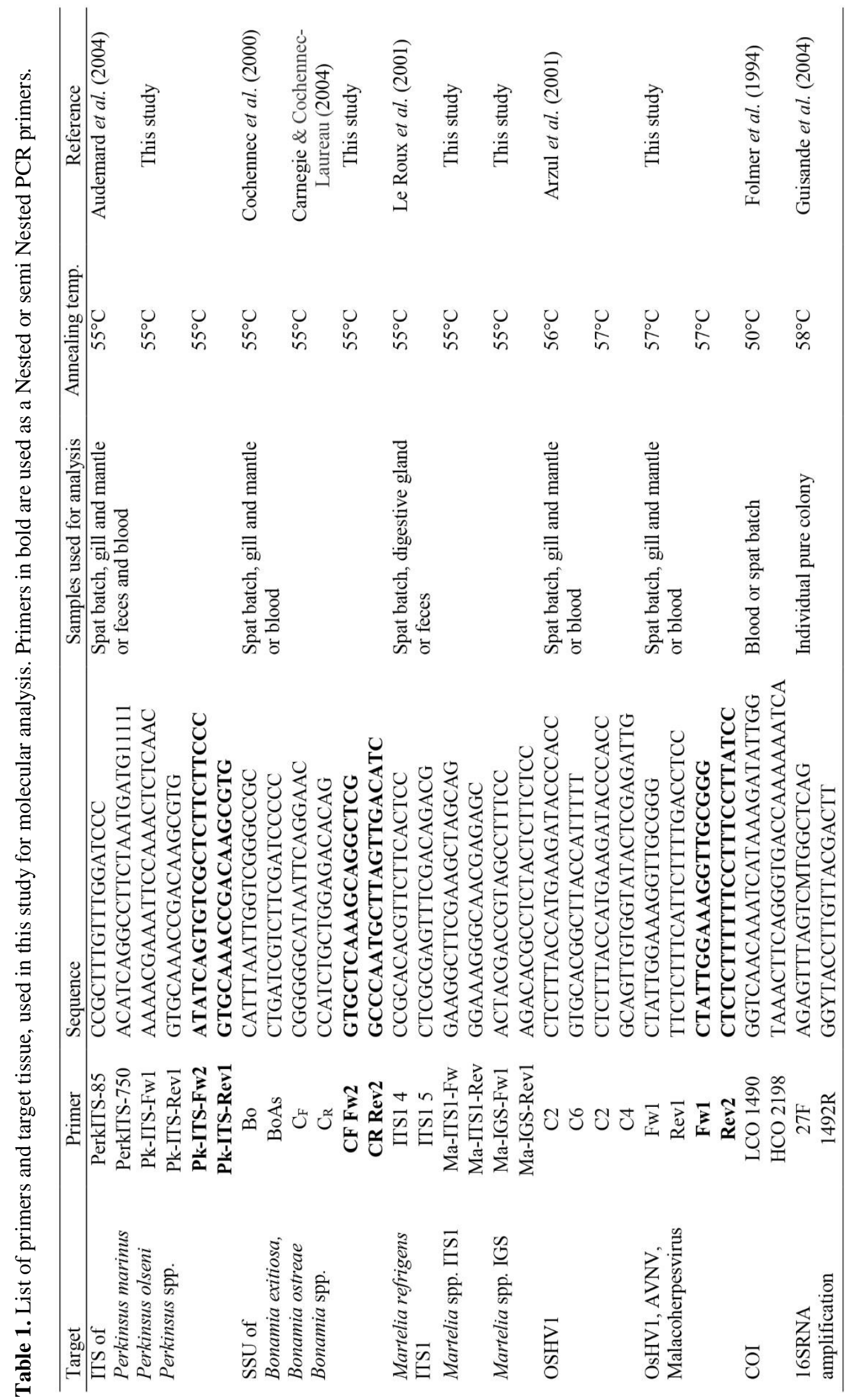


supplemented with $2 \% \mathrm{NaCl}$. Pure strains were identified based on their sequences of the 16S rRNA gene as described by Guisande et al. (2004). Briefly, $16 \mathrm{~S}$ rRNA was partially amplified using $27 \mathrm{~F}$ and 1492R primers (Table 1). PCR products were sequenced using internals primers $518 \mathrm{~F}$ and $800 \mathrm{R}$ at Macrogen Inc. (USA). Only high-quality sequences were used to reconstitute the 16S rRNA sequences which were then compared with GeneBank entries using BlastN to identify bacterial genus. The classifi-cation level was attributed as cording to their respective match with the database; species; $99-100 \%$, Genus; $97-98 \%$, family; $95-96 \%$.

\section{Pathological analyses}

Pathological analyses were performed on samples of moribund spats and adults, but also healthy adults and their offspring. Molecular biology diagnostics were realized using both primers and protocols recommended by the OIE for the detection of various pathogens of bivalves such as Bonamia exitiosa, Bonamia ostreae, Marteilia refringens, Perkinsus marinus, Perkinsus olseni, OSHV $1 \mu$ var or others specially designed in this study (Table 1). PCR controls assays were performed using primers specific for the COI gene for checking the quality of extracted DNA and the reagents (Table 1).

For OIE's recommended primers, diagnostic protocols were performed as detailed by their authors (Table 1). In the case of primers designed in this study, reactions were realized in a final volume of $50 \mu \mathrm{L}$, using the Platinum Taq DNA Polymerase kit (Invitrogen) and following supplier recommendations with the addition of Bovine serum albumin (0.04X). The PCR reactions were carried out under the following conditions: an initial denaturation for $5 \mathrm{~min}$ at $95^{\circ} \mathrm{C}$, then 35 cycles of denaturation for $30 \mathrm{~s}$ at $94^{\circ} \mathrm{C}$, annealing for $45 \mathrm{~s}$ at their respective temperature (Table 1), followed by extension for $1 \mathrm{~min}$ at $72^{\circ} \mathrm{C}$ and a final extension step of $7 \mathrm{~min}$ at $72^{\circ} \mathrm{C}$. When possible, primers for nested PCR assays were designed to increase the sensibility of the diagnostic.

\section{Population genetic analyses}

For COI amplification, primers used were as proposed by Folmer et al. (1994). PCR was performed in a total volume of $50 \mu \mathrm{L}$ including $1.5 \mathrm{U}$ High fidelity Platinium Taq DNA polymerase (Invitrogen), $100 \mathrm{ng}$ template DNA, 20 pmol of forward and reverse primers (LCO 1490 and HCO 2198), $0.2 \mathrm{mM}$ of each dNTP, $1 \mathrm{X}$ PCR buffer and $1.5 \mathrm{mM} \mathrm{MgCl}_{2}$. The PCR reaction was carried out under the following conditions: an initial denaturation for $5 \mathrm{~min}$ at $95^{\circ} \mathrm{C}$, then 35 cycles of denaturation for $30 \mathrm{~s}$ at $94^{\circ} \mathrm{C}$, annealing for $45 \mathrm{~s}$ at $50^{\circ} \mathrm{C}$, followed by extension for $1 \mathrm{~min}$ at $72^{\circ} \mathrm{C}$ and a final extension step of $7 \mathrm{~min}$ at $72^{\circ} \mathrm{C}$. PCR amplicons were sent to sequencing at Macrogen Inc. (USA). Sequences were edited with the software Mega5 (Tamura et al., 2013) and aligned by Muscle (Edgar, 2004).

Genealogical relationships among different haplotypes were investigated by applying maximum parsimony as implemented in TCS software (Clement et al., 2000). Haplotype (gene) diversity was calculated as in Nei (1987), by equations 8.4 but replacing $2 n$ by n. Nucleotide diversity (Nei, 1987), the average number of nucleotide differences per site between two sequences $(\pi)$, was also calculated. Haplotype and nucleotide diversities were estimated by using DnaSP v.5.10.01 (Librado \& Rozas, 2009).

\section{RESULTS}

\section{Reproduction and spat production}

From August 2010 to January 2011, 463 animals between 30 and $62 \mathrm{~mm}$ length were collected in the protected area of NSMT and kept in the hatchery as previously described. Gamete emission was successfully induced for 55 females and 54 males, i.e., $23.5 \%$ of the selected animals. Gametes recovered from these animals permitted to obtain 27 million of D larvae at 48 $\mathrm{h}$ after fertilization that means an average of 470,940 larvae D per female. The culture from planktonic trochophore stage to semi benthonic pediveliger stage lasted from 14 to 18 days at $25^{\circ} \mathrm{C}$ and 12 to 16 days at $29^{\circ} \mathrm{C}$, and lead to the obtaining of 17.2 million of pediveliger larvae (64\% survival).

The recovered pediveliger larvae were seeded at a density of 100 per $\mathrm{cm}^{2}$ and cultivated 20 to 25 days to obtain 0.6 to $1 \mathrm{~mm}$ spat. Survival from pediveliger larvae to spat ranged between 4 and $25 \%$ with an average of $11.8 \%$ and a total number of $1,932,000$ spats.

\section{Pathology}

Infectious pathology has been considered, on the one hand, as a crucial component of broodstock and spat certification for the production of pathogen-free spats permitting reliable aquaculture or stock enhancement operations and, on the other hand, to identify opportunistic and pathogenic bacteria present in a hatchery that could affect production.

PCR diagnostics were performed on the recommended tissue by the OIE, respectively gill and mantle (Bonamia spp., Perkinsus spp. and malacoherpesvirus) or digestive gland (Marteilia refringens) for moribund animals (21 individuals) and blood 


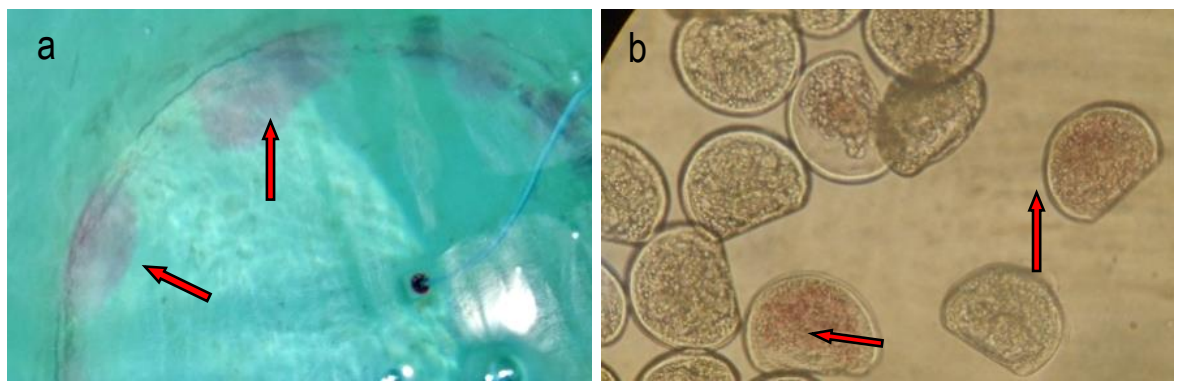

Figure 1. Massive mortalities in Anadara tuberculosa larval rearing tanks, in the presence of a pinkish biofilm. a) Pinkish biofilms at the bottom of the tank with moribund pink larvae; b) D larvae with pinkish tissues.

(Bonamia spp., Perkinsus spp. and malacoherpesvirus), and feces (Marteilia refringens, Perkinsus spp.) for healthy mollusks (60 individuals). All led to negative results. Similarly, all PCR analyses realized with homogenates of six healthy spat batches and three moribund spat batches (10-15 individuals per sample) were negative. In all the cases, amplicons were obtained for the PCR positive controls with primers specific of COI gene that showed the quality of extracted DNAs and reagents.

Putatively pathogenic bacteria have been isolated from moribund adults and larvae during a mortality event that occurred in January 2011. In this outbreak, the presence of a pinkish biofilm has been noticed at the bottom of larval tanks and the tissue from moribund larvae also exhibited the same pinkish color (Fig. 1).

Blood samples from eight moribund adults were collected along with pink D larvae and biofilm. A total of 36 bacterial strains were isolated; four from biofilm samples, eight from D larvae and 24 from adults (Table 2 ). Those strains were grouped in five clusters by their 16SrRNA sequences where Vibrio and Pseudomonas genus were dominant. Microbiological analysis indicated that the pink biofilm observed in tanks with moribund adults and pink spat was related to the presence of Pseudomonas. Such pink biofilm was also seen in rearing tanks with moribund larvae and juveniles of the whiteleg shrimp Penaeus vannamei within the hatchery during this study.

A single strain, CNLS1P, has been isolated from the pink biofilm and was identified as Pseudomonas sp. (based on 99\% percentage of similarity with Pseudomonas 16SRNAr JN684003.1 sequence in Genbank). This strain has also been found on infected D larvae.

Samples extracted from blood samples of moribund Anadara tuberculosa showed a higher bacterial diversity and six genetically distinct strains had been isolated. Interestingly, the same Pseudomonas strains CNLS1P was found in all blood samples. Another distinct Pseudomonas strain CNAs10 was also identified but could be found only in one adult. Additionally, four different members of the Vibrionaceae family were isolated, with the strains CNLS2V that was also found on D larvae. Strains CNLS2V and CNAs4 closest match belonged to Vibrio genus but with only $96 \%$ of similarity and were thus classified as Vibrionaceae. Two additional strains were identified as Vibrio shilonii CNAV11 and Vibrio shilonii CNAV2 with $99 \%$ correspondence.

\section{Population genetic analyses}

In this study, we have evaluated A. tuberculosa population diversity based on their COI gene. Data were obtained from 111 animals collected in seven areas of the NSMT. All sequences obtained were processed by Blast (NCBI) and showed 99 to $100 \%$ homology with the A. tuberculosa COI reference sequence. Of the 111 sequences, 39 haplotypes were identified. Haplotype and nucleotide diversity are reported in Table 3. Overall haplotype diversity was 0.898 (standard deviation, SD = 0.021). Haplotype diversity ranged from $0.826 \pm 0.073(\mathrm{Z} 2)$ to $0.958 \pm$ 0.036 (Z7). These two locations also exhibited lower and higher nucleotide diversity ( $\pi=0.004 \pm 0.001$ for $\mathrm{Z} 2$, and $0.008 \pm 0.001$ for Z7).

Figure 2 represents genealogical relationships between the 39 haplotypes of $A$. tuberculosa from the NSMT. The size of circles and square is proportional to the frequency of the haplotype.

Some haplotypes were more prevalent than others, such as haplotype 1 (31 ind), 26 (13 ind), 13 ( 7 ind), 17, 28 and 33 (6 ind each), that represent $27.9 \%, 11.7 \%$, $6.3 \%$, and $5.4 \%$, respectively, of the total population. According to Clement et al. (2000), for its high frequency, haplotype 1 could be considered the "ancestor" haplotype. Also, it is the only haplotype found in all areas, with a rate varying from 6.25 (Z7) to $40.0 \%$ (Z2). $44.7 \%$ of haplotypes were found only in a 
Table 2. Cultivable bacterial strains isolated from Anadara tuberculosa rearing tanks and moribund adults and larvae. Strains were identified based on their 16S RNAr sequences.

\begin{tabular}{lclccc}
\hline Sample & $\begin{array}{c}\text { Number of bacterial } \\
\text { isolates per group }\end{array}$ & Strain name & $\begin{array}{c}\text { 16SRNA identification } \\
\text { gene nearest neighbor }\end{array}$ & $\begin{array}{c}\text { Sequence } \\
\text { similarity }\end{array}$ & $\begin{array}{c}\text { Closest GenBank } \\
\text { number }\end{array}$ \\
\hline Biofilm & 4 out of 4 & CNLS1P & Pseudomonas sp. & $99 \%$ & JN684003.1 \\
Larva & 4 out of 8 & CNLS1P & Pseudomonas sp. & $99 \%$ & JN684003.1 \\
Larva & 4 out of 8 & CNLS2V & Vibrionaceae & $96 \%$ & AP014635.1 \\
Adult & 2 out of 24 & CNLS2V & Vibrionaceae & $96 \%$ & NR_146027.1 \\
Adult & 13 out of 24 & CNLS1P & Pseudomonas sp. & $99 \%$ & JN684003.1 \\
Adult & 1 out of 24 & CNAs10 & Pseudomonas sp. & $99 \%$ & KT695822.1 \\
Adult & 2 out of 24 & CNAs4 & Vibrionaceae & $96 \%$ & KP713778.1 \\
Adult & 3 out of 24 & CNAV11 & Vibrio shilonii & $99 \%$ & HF541940.1 \\
Adult & 3 out of 24 & CNAV2 & Vibrio shilonii & $99 \%$ & AY911395.1 \\
\hline
\end{tabular}

Table 3. Haplotype and nucleotide diversity of Anadara tuberculosa from the National Sanctuary Mangrove of Tumbes based on mitochondrial COI sequences.

\begin{tabular}{lcccc}
\hline Extraction site & $\begin{array}{c}\text { \# of sequences } \\
\text { analyzed }\end{array}$ & $\begin{array}{c}\text { \# of different } \\
\text { haplotypes }\end{array}$ & $\begin{array}{c}\text { Haplotype } \\
\text { diversity }\end{array}$ & $\begin{array}{c}\text { Nucleotide } \\
\text { diversity }(\pi)\end{array}$ \\
\hline Z1 La Abeja & 18 & 9 & $0.889 \pm 0.049$ & $0.007 \pm 0.001$ \\
Z2 Chorro de la Almeja & 20 & 9 & $0.826 \pm 0.073$ & $0.004 \pm 0.001$ \\
Z3 El Habilitado & 19 & 13 & $0.877 \pm 0.074$ & $0.006 \pm 0.001$ \\
Z4 La Chalaquera & 14 & 9 & $0.912 \pm 0.059$ & $0.004 \pm 0.001$ \\
Z5 Corral de los Coches & 12 & 8 & $0.894 \pm 0.078$ & $0.005 \pm 0.001$ \\
Z6 Nacupillal & 11 & 7 & $0.909 \pm 0.066$ & $0.007 \pm 0.002$ \\
Z7 Las Agujillas & 16 & 12 & $0.958 \pm 0.036$ & $0.008 \pm 0.001$ \\
\hline Total & 111 & 39 & $0.898 \pm 0.021$ & $0.006 \pm 0.0005$ \\
\hline
\end{tabular}

single site, with Z6 being the more diverse site $(61.5 \%)$ and $\mathrm{Z} 3$ the lesser one (28.6\%).

\section{DISCUSSION}

\section{Spat production}

In this study, brooders with sizes between $45-60 \mathrm{~mm}$ were successfully induced to spawn by a progressive heat shock. Spawning prevalence $(23.5 \%)$ and D larvae produced per female $(470,000)$ were lower than those reported by Vásquez et al. (2009) with $40 \%$ and 2-3 billion D larvae, probably due to the bigger size of their brooders $(50-80 \mathrm{~mm})$. Such sizes are nowadays almost inexistent in the NSMT due to overexploitation.

\section{Genetics}

Hatchery produced shellfish larvae may lead to reduced genetic diversity resulting from the utilization of a limited number of brooders and to higher fitness of some genotypes in artificial culture conditions. Genetic diversity is a crucial component for populations' adaptive response to environmental conditions and long-term viability of aquaculture or stock enhancement programs. Consequently, the production and release of hatchery-reared larvae must be performed considering the management of genetic diversity at intra- and interpopulation levels. In this study, we used the mtCOI gene as a barcoding marker for the evaluation of Anadara tuberculosa genetic diversity in the NSMT.

Results indicate that the NSMT population presents a very high level of haplotype diversity which is essential considering the limited size of the sampled area (10 linear $\mathrm{km}$ between the two farthest extraction points). The star-like shape of the TCS network and the shallow length of branches (the maximum distance between the ancestor haplotype and the most divergent haplotype corresponds to only seven nucleotides) would suggest a recent population expansion (Clement et al., 2000). As a point of comparison, haplotype diversity of A. tuberculosa from the NSMT was higher (36.7 vs 28.5\%) than the genetic diversity reported for the same species extracted from Nariño region (Colombia) by Chamorro \& Rosero (2016) or from Anadara granosa from Malaysia (14.7\%) (Chee et al., 2011b). 


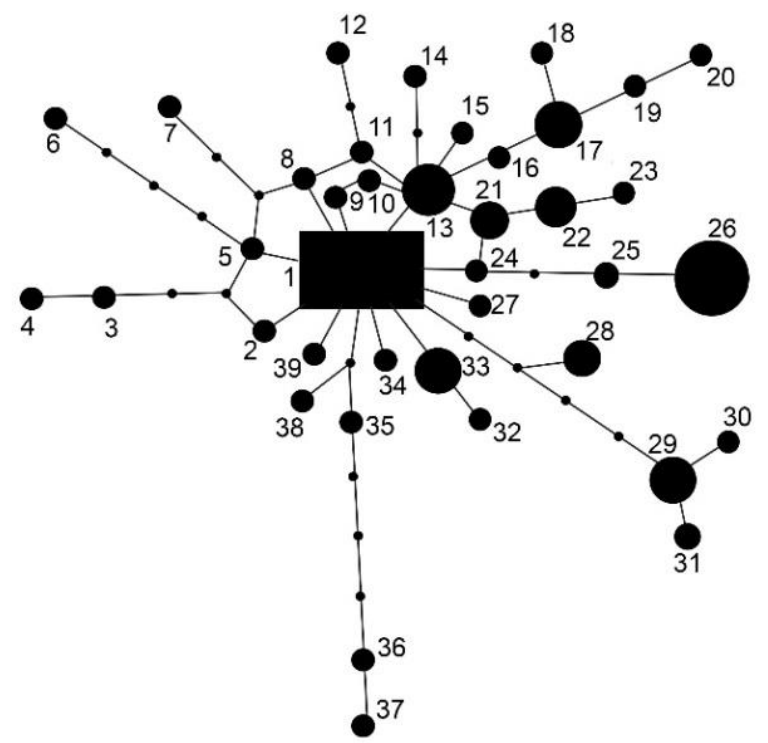

Figure 2. Maximum Parsimony Network. It represents the genealogical relationships between the 39 haplotypes of Anadara tuberculosa from the NSMT, based on COIgene partial sequence. The size of circles is proportional to the number of individuals that share the same haplotype. "Ancestor" haplotype is symbolized by a square base and corresponds to the most frequent haplotype (1). Every nucleotide switch generates a difference that is represented by a line (branch) between circles. Smaller circles correspond to missing haplotypes that could exist but have not been sampled or extinct haplotypes.

The extension of A. tuberculosa genetic study to other South American population would help to gain information on intraspecific genetic flow and would help to understand the poorly understood patterns of larval dispersion of this bivalve. Research in this regard has started, indicating the importance of oceanic currents and palaeoclimatic events in shaping patterns of genetic variation of the species (Diringer et al., 2019). This information would have significant implications for fishery management, conservation, translocation policies for aquaculture and stock enhancement programs.

\section{Pathology}

Diseases are a primary threat to mollusk aquaculture growth and sustainability, to the extreme that some have led that rearing activity stopped and that natural stocks have been decimated (Guo \& Ford, 2015). Like for other invertebrates, such as shrimp, transfers of hatchery-produced larvae to grow-out areas are probably crucial in disease dissemination. Nevertheless, hatchery productions may also be a way to provide disease-free juveniles and therefore be a critical tool to prevent the transfer of infected stocks to disease-free areas. In that sense, the present work relies on early molecular diagnostic to avoid disease transmission. Such a strategy is nowadays common in other aquaculture activity such as shrimp farming (Lo et al., 1998; Motte et al., 2003). Despite the fact that A. tuberculosa rearing is an emerging activity and that no infectious pathogen has been documented, early disease diagnostic is justified because: 1) three OIE listed pathogens are present in Latin America (Cremonte et al., 2005; Wetchateng, 2008), 2) other ark species are known to be infected by Perkinsus species (Goggin \& Baker, 1993) or OsHV1 (Xia et al., 2015).

During this study, mortalities have happened during culture, but none could have been associated with one of the infectious disease sought by molecular diagnostic in either broodstock or spats. However, microbiological analyses revealed the presence of some cultivable bacterial pathogens, in particular, a Pseudomonas sp. and Vibrionaceae strains during outbreaks in both larvae and broodstock.

Members of the genus Pseudomonas have been occasionally described as pathogens for bivalve larvae, (Brown, 1973, 1981; Lodeiros et al., 1992; Romalde et al., 2014), but were generally co-isolated with representatives of the genus Vibrio that have been frequently incriminated to cause important losses in hatcheries and in native populations (Travers et al., 2015; Petton et al., 2015; Dubert et al., 2017). Nevertheless, it is often difficult to distinguish between pathogenic bacteria and the native microbiome of the bivalve. In fact, Vibrio species predominate in the cultivable microbiota in bivalves (Garnier et al., 2007; Romalde et al., 2014) and arks (Kueh \& Chan, 1985; Bilung et al., 2005; Ahmad et al., 2014; Sanchez et al., 2015), while Pseudomonas is also commonly found in arks (Romanenko et al., 2008; Ahmad et al., 2014). In this study, the presence of Pseudomonas sp. strain CNLS1P was correlated with the presence of a pink biofilm and significant mortalities in all spat and adult samples which suggest its implication with those outbreaks. Also, no ubiquitous strain of Vibrio or Vibrionaceae could be identified as it is the case with the CNLS1P strain. Experimental infection realized per os or by injection on healthy adults of Anadara tuberculosa and Penaeus vannamei juveniles indicates that this Pseudomonas strain is particularly pathogenic to both organisms with or without association with Vibrio species (data not shown).

All isolated strains were molecularly characterized by sequencing their 16SRNAr gene which is considered as the gold standard for phylogenetic analysis of bacteria (Klindworth et al., 2012). Nevertheless, few strains were able to be identified to the species level, and two strains were only classified at the family level 
(CNAs4 and CNLS2V as Vibrionaceae). Multilocus sequence analyses (MLSA) could be realized for further genetic discrimination within Vibrios' clades (Travers et al., 2015). The use of next-generation sequencing tools to study the metagenome of bivalves' native or pathogenic bacteria appears also as an interesting option, with the possibility to detect cultivable, co-cultivable and uncultivable strains (King et al., 2012; Trabal et al., 2012; Wegner et al., 2013; Wendling et al., 2014), in particular by characterizing bivalves' microbial composition following experimental infection with Vibrio sp. (Lockmer \& Wegner, 2015).

\section{CONCLUSIONS}

This project, developed in the particular context of a biosphere reserve, aimed to pave the way for the sustainable production of spats of the pustulose ark, for aquaculture and stock enhancement purposes, considering three components: 1) spat output by classical aquaculture/biotechnology methods, 2) early pathology diagnostic so that vertical and horizontal disease transmission could be prevented or at least diagnosed, and 3) pustulose ark' genetic diversity estimation in order to perform responsible genetic management.

The results presented in this study have shown the feasibility to produce specific disease-free spat and also highlighted the relatively high genetic diversity of natural populations from the NSMT.

Altogether, this work illustrates the need to integrate classical biotechnologies with modern molecular biotechnology and offers a model for future stock enhancement strategies. The sustainability of such projects will require building collaborations among government institutions, environmental groups, aquaculture private-sector and the scientific community.

\section{ACKNOWLEDGMENTS}

The authors would like to thank the anonymous reviewers for their helpful and constructive comments that greatly contributed to improving the final version of this manuscript. This research was funded by the FINCyT (assignment $\mathrm{N}^{\circ} 71$-FINCYT-PITEI-2010), the Concytec (assignment 132-2015-FONDECYT) and with private funds from MEDA, Marinazul, Inversiones Silma, Incabiotec, and Concepto Azul. B.D. was supported by a scholarship from the Franco Peruvian School of Life Sciences.

\section{REFERENCES}

Ahmad, A., Mehat, N.D., Hamid, R. \& Usup, G. 2014. Population density and antibiotic resistant of bacteria from bivalve (Perna viridis and Anadara granosa). Sains Malaysiana, 43(4): 543-550.

Arnold, W.S., Blake, N.J., Harrison, M.M., Marelli, D.C., Parker, M.L., Peters, S.C. \& Sweat, D.E. 2005. Restoration of bay scallop (Argopecten irradians (Lamarck)) populations in Florida coastal waters: planting techniques and the growth, mortality and reproductive development of planted scallops. Journal of Shellfish Research, 24(4): 883-904.

Arnold, W.S. 2008. Application of larval release for restocking and stock enhancement of coastal marine bivalve populations. Reviews in Fisheries Science, 16(1-3): 65-71. doi: 10.1080/10641260701678140.

Arzul, I., Renault, T., Lipart, C. \& Davison, A.J. 2001. Evidence for interspecies transmission of oyster herpesvirus in marine bivalves. Journal of General Virology, 82(4): 865-870. doi: 10.1099/0022-131782-4-865.

Arzul, I., Langlade, A., Chollet, B., Robert, M., Ferrand, S., Omnes, E., Lerond, S., Couraleau, Y., Joly, J.P., François, C. \& Garcia, C. 2010. Can the protozoan parasite Bonamia ostreae infect larvae of flat oysters Ostrea edulis? Veterinary Parasitology, 179(1-3): 6976. doi: 10.1016/j.vetpar.2011.01.060.

Audemard, C., Reece, K.S. \& Burreson, E.M. 2004. Realtime PCR for detection and quantification of the protistan parasite Perkinsus marinus in environmental waters. Applied and Environmental Microbiology, 70(11): 6611-6618. doi: 10.1128/AEM.70.11.66116618.2004.

Baqueiro, E., Massó, J.A. \& Guajardo, H. 1982. Distribución y abundancia de moluscos de importancia comercial en Baja California Sur. Instituto Nacional de la Pesca, Secretaría de Pesca, Ciudad de México.

Bell, J.D., Rothlisberg, P.C. \& Munro, J.L. 2005. Restocking and stock enhancement of marine invertebrate fisheries. Advances in Marine Biology, 49: 11-12. doi: 10.1016/S0065-2881(05)49010-0.

Berthe, F.C. 2005. Diseases in mollusc hatcheries and their paradox in health management. Diseases in Asian Aquaculture. Fish Health Section, Asian Fisheries Society, Manila, V: 239-248.

Bilung, L.M., Radu, S., Bahaman, A.R., Rahim, R.A., Napis, S., Ling, M. \& Nishibuchi, M. 2005. Detection of Vibrio parahaemolyticus in cockle (Anadara granosa) by PCR. FEMS Microbiology Letters, 252(1): 85-88. doi: 10.1016/j.femsle.2005.08.053.

Brown, C. 1973. The effects of some selected bacteria on embryos and larvae of the American oyster, Crassostrea virginica. Journal of Invertebrate Pathology, 21(3): 215-223. doi: 10.1016/0022-2011(73) 90206-1. 
Brown, C. 1981. A study of two shellfish-pathogenic Vibrio strains isolated from a Long Island hatchery during a recent outbreak of disease. Journal of Shellfish Research, 1: 83-87.

Camacho, Y. 1999. Especies de Costa Rica. Anadara tuberculosa. Instituto Nacional para la Biodiversidad, San José.

Carnegie, R.B. \& Cochennec-Laureau, N. 2004. Microcell parasites of oysters: recent insights and future trends. Aquatic Living Resources, 17(4): 519-528. doi: 10.1051/alr:2004055.

Chamorro, E. \& Rosero, C. 2016. Estimación de la diversidad genética de Anadara tuberculosa en cinco manglares de Tumaco, utilizando la enzima citocromo oxidasa I. Revista MVZ Córdoba, 21(3): 5547-5557. doi:10.21897/rmvz.829.

Chee, S.Y., Azizah, M.N.S. \& Devakie, M.N. 2011a. Utilization of molecular markers for the conservation of blood cockles, Anadara granosa (Arcidae). Genetics and Molecular Research, 10(2): 1245-1261. doi: 10.4238/vol10-2gmr1103.

Chee, S.Y., Devakie, M.N. \& Azizah, M.S. 2011 b. Phylogenetic study and barcoding of the blood cockle, Tegillarca granosa, found on the west coast of peninsular Malaysia using the COI gene. Genetics and Molecular Research, 10(2): 1237-1244. doi: 10.4238/ vol10-2gmr1104.

Cho, E.S., Jung, C.G., Sohn, S.G., Kim, C.W. \& Han, S.J. 2007. Population genetic structure of the ark shell Scapharca broughtonii Schrenck from Korea, China, and Russia based on COI gene sequences. Marine Biotechnology, 9(2): 203-216. doi: 10.1007/s10126006-6057.

Clement, M., Posada, D. \& Crandall, K.A. 2000. TCS: a computer program to estimate gene genealogies. Molecular Ecology, 9(10): 1657-1660. doi: 10.1046/ j.1365-294x.2000.01020.x.

Cochennec, N., Le Roux, F., Berthe, F. \& Gerard, A. 2000. Detection of Bonamia ostreae based on small subunit ribosomal probe. Journal of Invertebrate Pathology, 76(1): 26-32. doi: 10.1006/jipa.2000.4939.

Cremonte, F., Balseiro, P. \& Figueras, A. 2005. Occurrence of Perkinsus olseni (Protozoa: Apicomplexa) and other parasites in the venerid commercial clam Pitar rostrata from Uruguay, southwestern Atlantic coast. Diseases of Aquatic Organisms, 64(1): 85-90. doi: 10.3354/dao064085.

Diringer, B., Pretell, K., Avellan, R., Chanta, C., Cedeño, V. \& Gentile, G. 2019. Genetic structure, phylogeography, and demography of Anadara tuberculosa (Bivalvia) from East Pacific as revealed by mtDNA: implications to conservation. Ecology and Evolution, 9(8): 4392-4402. doi: 10.1002/ece3.4937.
Dubert, J., Barja, J.L. \& Romalde, J.L. 2017. New insights into pathogenic Vibrios affecting bivalves in hatcheries: present and future prospects. Frontiers in Microbiology, 8: 16 pp. doi: 10.3389 /fmicb.2017. 00762.

Edgar, R.C. 2004. MUSCLE: multiple sequence alignment with high accuracy and high throughput. Nucleic Acids Research, 32(5): 1792-1797. doi: 10.1093/nar/ gkh340.

Feng, Y., Li, Q., Kong, L. \& Zheng, X. 2011. COI-based DNA barcoding of Arcoida species (Bivalvia: Pteriomorphia) along the coast of China. Molecular Ecology Resources, 11(3): 435-441. doi: 10.1111 /j.1755-0998.2010.02975.x.

Folmer, O., Black, M., Hoeh, W., Lutz, R. \& Vrijenhoek, R. 1994. DNA primers for amplification of mitochondrial cytochrome c oxidase subunit I from diverse metazoan invertebrates. Molecular Marine Biology and Biotechnology, 3: 294-299.

Gaffney, P.M. 2006. The role of genetics in shellfish restoration. Aquatic Living Resources, 19(3): 277282. doi: 10.1051/alr:2006028.

Garnier, M., Labreuche, Y., Garcia, C., Robert, M. \& Nicolas, J.L. 2007. Evidence for the involvement of pathogenic bacteria in summer mortalities of the Pacific oyster Crassostrea gigas. Microbial Ecology, 53(2): 187-196. doi: 10.1007/s00248-006-9061-9.

Goggin, C.L. \& Barker, S.C. 1993. Phylogenetic position of the genus Perkinsus (Protista, Apicomplexa) based on small subunit ribosomal RNA. Molecular and Biochemical Parasitology, 60(1): 65-70. doi: 10.1016/ 0166-6851(93)90029-W.

Guisande, J.A., Montes, M., Farto, R., Armada, S.P., Perez, M.J. \& Nieto, T.P. 2004. A set of tests for the phenotypic identification of culturable bacteria associated with Galician bivalve mollusk production. Journal of Shellfish Research, 23(2): 599-609.

Guo, X. \& Ford, S.E. 2016. Infectious diseases of marine mollusks and host responses as revealed by genomic tools. Philosophical Transactions of the Royal Society B: Biological Sciences, 371(1689): 20150206. doi: 10.1098/rstb.2015.0206.

Helm, M.M., Bourne, N. \& Lovatelli, A. 2004. Hatchery culture of bivalves. A practical manual. Fisheries Technical Paper FAO, Rome, 471.

King, G.M., Judd, C., Kuske, C.R. \& Smith, C. 2012. Analysis of stomach and gut microbiomes of the eastern oyster (Crassostrea virginica) from coastal Louisiana, USA. Plos One, 7(12): e51475. doi: 10.1371/journal.pone.0051475.

Klindworth, A., Pruesse, E., Schweer, T., Peplies, J., Quast, C., Horn, M. \& Glöckner, F.O. 2012. 
Evaluation of general 16S ribosomal RNA gene PCR primers for classical and next-generation sequencingbased diversity studies. Nucleic Acids Research, 41(1): e1. doi: 10.1093/nar/gks808.

Kueh, C.S. \& Chan, K.Y. 1985. Bacteria in bivalve shellfish with special reference to the oyster. Journal of Applied Microbiology, 59(1): 41-47.

Lallias, D., Boudry, P., Lapegue, S., King, J.W. \& Beaumont, A.R. 2010. Strategies for the retention of high genetic variability in European flat oyster (Ostrea edulis) restoration programs. Experientia Supplementum, 11(5): 1899-1910. doi: 10.1007/s10592-0100081-0.

Le Roux, F., Lorenzo, G., Peyret, P., Audemard, C., Figueras, A., Vivarès, C. \& Berthe, F. 2001. Molecular evidence for the existence of two species of Marteilia in Europe. Journal of Eukaryotic Microbiology, 48(4): 449-454. doi: 10.1111/j.1550-7408.2001.tb00178.x.

Librado, P. \& Rozas, J. 2009. DnaSP v5: a software for comprehensive analysis of DNA polymorphism data. Bioinformatics, 25(11): 1451-1452. doi: 10.1093/ bioinformatics/btp187.

Lo, C.F., Chang, Y.S., Cheng, C.T. \& Kou, G.H. 1998. PCR monitoring of cultured shrimp for white spot syndrome virus (WSSV) infection in grow-out ponds. In: Flegel, T.W. (Ed.). Advances in shrimp biotechnology. National Center for Genetic Engineering and Biotechnology, Bangkok, pp. 281-286.

Lodeiros, C., Freites, L. \& Vélez, A. 1992. Necrosis bacilar en larvas del bivalvo Euvola ziczac (Linneo, 1758) causada por una Pseudomonas sp. Acta Científica Venezolana, 43(3): 154-158.

Lockmer, A. \& Wegner, K.M. 2015. Hemolymph microbiome of Pacific oysters in response to temperature, temperature stress, and infection. The ISME Journal, 9(3): 670-682. doi: 10.1038/ismej. 2014.160.

López-Sanmartín, M., Power, D.M., De La Herrán, R., Navas, J.I. \& Batista, F.M. 2016. Evidence of vertical transmission of ostreid herpesvirus 1 in the Portuguese oyster Crassostrea angulata. Journal of Invertebrate Pathology, 140: 39-41. doi: 10.1016/j.jip. 2016.08.012.

Lucero, C., Cantera, J. \& Neira, R. 2012. Pesquería y crecimiento de la piangua (Arcoida: Arcidae) Anadara tuberculosa en la Bahía de Málaga del Pacífico colombiano. Revista de Biología Tropical, 60(1): 203217. doi: 10.15517/rbt.v60i1.

McCay, D.P.F., Peterson, C.H., De Alteris, J.T. \& Catena, J. 2003. Restoration that targets function as opposed to structure: replacing lost bivalve production and filtration. Marine Ecology Progress Series, 264: 197212. doi: $10.3354 /$ meps264197.

Mora, E., Moreno, J. \& Jurado, V. 2011. Un análisis de la pesquería del recurso concha en Ecuador durante el
2010. Instituto Nacional de Investigaciones en Metrología, 21(2): 1-13.

Motte, E., Yugcha, E., Luzardo, J., Castro, F., Leclercq, G., Rodríguez, J. \& Montalvo, K. 2003. Prevention of IHHNV vertical transmission in the white shrimp Litopenaeus vannamei. Aquaculture, 219(1): 57-70. doi: 10.1016/S0044-8486(02)00631-2.

Nei, M. 1987. Molecular evolutionary genetics. Columbia University Press, New York.

Ordinola, E., Montero, P., Alemán, S. \& Llanos, J. 2010. El bivalvo concha negra, Anadara tuberculosa (Sowerby), en los manglares de Tumbes, Perú. Febrero 2007. Instituto del Mar del Perú, 37(3-4): 115-126.

Petton, B., Bruto, M., James, A., Labreuche, Y., AlunnoBruscia, M. \& Le Roux, F. 2015. Crassostrea gigas mortality in France: the usual suspect, a herpes virus, may not be the killer in this polymicrobial opportunistic disease. Frontiers in Microbiology, 6: 686. doi: 10.3389/fmicb.2015.00686.

Powell, E.N. \& Hofmann, E.E. 2015. Models of marine molluscan diseases: trends and challenges. Journal of Invertebrate Pathology, 131: 212-225. doi: 10.1016/ j.jip.2015.07.017.

Robles-Mungaray, M., Reynoso-Granados, T., MonsalvoSpencer, P. \& Omar-Castro, P. 1999. Cultivo larvario de pata de mula (Anadara tuberculosa) en Baja California Sur, México. Memorias del VII Congreso de la Asociación de Investigadores del Mar de Cortés - I Simposium Internacional sobre el Mar de Cortés. Hermosillo, Sonora, pp. 25-28.

Romanenko, L.A., Uchino, M., Kalinovskaya, N.I. \& Mikhailov, V.V. 2008. Isolation, phylogenetic analysis and screening of marine mollusc-associated bacteria for antimicrobial, hemolytic and surface activities. Microbiological Research, 163(6): 633-644. doi:10.1016/j.micres.2006.10.001.

Romalde, J.L., Dieguez, A.L., Lasa, A. \& Balboa, S. 2014. New Vibrio species associated to molluscan microbiota: a review. Frontiers in Microbiology, 4(413): 1-12. doi:10.3389/fmicb.2013.00413.

Sánchez, A., Luna, A., Campa, A., Escamilla, R., Flores, M. \& Mazón, J. 2015. Isolation and characterization of potential probiotic bacteria from pustulose ark (Anadara tuberculosa) suitable for shrimp farming. Latin American Journal of Aquatic Research, 43(1): 123-136. doi: 10.3856/vol43-issue1-fulltext-11.

Tamura, K., Stecher, G., Peterson, G., Filipski, A. \& Kumar, S. 2013. MEGA6: Molecular evolutionary genetics analysis version 6.0. Molecular Biology and Evolution, 30: 2725-2729. doi: 10.1093/molbev/ mst197. 
Tanaka, T. \& Aranishi, F. 2013. Mitochondrial DNA markers for PCR-based phylogenetic analysis of ark shells. Open Journal of Marine Science, 3(4): 182-189. doi: 10.4236/ojms.2013.34021.

Tanaka, T. \& Aranishi, F. 2014. Genetic variability and population structure of ark shell in Japan. Open Journal of Marine Science, 4: 8-17. doi: 10.4236/ojms. 2014.41002.

Tanaka, T. \& Aranishi, F. 2016. Comparative genetic characterization of ark shell Scapharca broughtonii in Northeast Asia. Journal of Shellfish Research, 35(2): 421-427. doi: 10.2983/035.035.0216.

Trabal, N., Mazón, S.J.M., Vázquez, J.R., Asencio, V.F., Morales, B.E. \& Romero, J. 2012. Molecular analysis of bacterial microbiota associated with oysters (Crassostrea gigas and Crassostrea corteziensis) in different growth phases at two cultivation sites. Microbial Ecology, 64(2): 555-569. doi: 10.1007/ s00248-012-0039-5.

Travers, M.A., Miller, K.B., Roque, A. \& Friedman, C.S. 2015. Bacterial diseases in marine bivalves. Journal of Invertebrate Pathology, 131: 11-31. doi: 10.1016/ j.jip.2015.07.010.

Vásquez, H.E., Pacheco-Reyes, S.P., Púrez-García, I.M., Cornejo-Hernández, N.E., Córdoba-Navas, M.F. \& Kani, K. 2009. Producción artificial de semilla y cultivo de engorde de moluscos bivalvos. Ministerio de Agricultura y Ganadería, La Libertad. Centro de Desarrollo de la Pesca y la Acuicultura, Usulután, pp. 53-73.

Received: 20 August 2018; Accepted: 19 April 2019
Vivar, L. 1996. Dinámica poblacional y tasa de explotación de Anadara tuberculosa (Sowerby, 1833) "concha negra'” en los manglares de Puerto Pizarro, Tumbes-Perú. Noviembre 1995-Agosto 1996. Tesis Maestría en Ciencias, Universidad Nacional de Trujillo, Trujillo, 67 pp.

Wegner, K.M., Volkenborn, N., Peter, H. \& Eiler, A. 2013. Disturbance-induced decoupling between host genetics and the composition of the associated microbiome. BMC Microbiology, 13(1): 2-12. doi: 10.1186/1471-2180-13-252.

Wendling, C.C., Batista, F.M. \& Wegner, K.M. 2014. Persistence, seasonal dynamics and pathogenic potential of Vibrio communities from Pacific oyster hemolymph. Plos One, 9(4): 1-12. doi: 10.1371/ journal.pone.0094256.

Wetchateng, T. 2008. Rickettsia-like organism (RLO) infection in the abalone Haliotis diversicolor supertexta: histopathology, diagnosis, and treatment. Doctoral Dissertation, Mahidol University, Bangkok.

Xia, J., Bai, C., Wang, C., Song, X. \& Huang, J. 2015. Complete genome sequence of Ostreid herpesvirus-1 associated with mortalities of Scapharca broughtonii broodstocks. Virology Journal, 12(1): 110. doi: 10.1186/s12985-015-0334-0. 